\title{
KAJIAN VARIASI CAMPURAN BUBUR KERTAS Terhadap Nilai Penetrasi Dan Permeabilitas Beton
}

\author{
Arqowi Pribadi ${ }^{1}$ \\ ${ }^{1)}$ Prodi Teknik Lingkungan, Fakultas Sains dan Teknologi, UIN Sunan Ampel Surabaya \\ Jln. Jend. A. Yani 117 Kota Surabaya, Jawa Timur, 60237 \\ E-mail : arqowi.pribadi@uinsby.ac.id
}

\begin{abstract}
Papercrete is made from used newspaper processed into pulp mixed with portland cement (PC), sand and water. This study uses a study of experimental methods that have been carried out in the laboratory on the weight of paper, cement, sand (KSP) with a variation of the ratio of KSP 1: 1: 1, KSP 2: 1: 1, KSP 3:1:1 with FAS 1. Cylindrical specimens have a diameter of 75 $\mathrm{mm}$ with a height of $275 \mathrm{~mm}$ with a number of 9 pieces for penetration and permeability tests with three specimens of each variation of the mixture. Penetration and permeability testing aims to determine the value of depth and breakdown of water entering through papercrete pores against 28 day old concrete samples. The test results obtained the smallest water penetration depth on $111 \mathrm{KSP}$ specimens of $0.0278 \mathrm{~m}$, while the largest water penetration depth on KSP 311 specimens was $0.0427 \mathrm{~m}$. The results of the smallest permeability coefficient analysis on the KSP 111 test object amounted to $2.13505 \times 10^{-7}$ $\mathrm{m} / \mathrm{dt}$ and the largest on KSP 311 specimens worth $2.29956 \times 10^{-6} \mathrm{~m} / \mathrm{s}$. Papercrete is an alternative environmentally friendly material used for non structural purposes such as wall partitions, substitutes for paving blocks, panels for walls and infiltration wells.
\end{abstract}

Keywords: Papercrete, The Value of Penetration and Permeability, Variation Proportion

\begin{abstract}
Abstrak
Papercrete terbuat dari kertas koran bekas diolah menjadi bubur kertas dicampurkan dengan bahan portland cement (PC), pasir dan air. Penelitian ini menggunakan kajian metode eksperimental yang pernah dilakukan di laboratorium terhadap berat kertas, semen, pasir (KSP) dengan variasi perbandingan KSP 1:1:1, KSP 2:1:1, KSP 3:1:1 dengan nilai FAS 1. Benda uji silinder memiliki diameter $75 \mathrm{~mm}$ dengan tinggi $275 \mathrm{~mm}$ sejumlah 9 buah untuk uji penetrasi dan permeabilitas dengan tiga benda uji setiap variasi campurannya. Pengujian penetrasi dan permeabilitas bertujuan mengetahui nilai kedalaman dan kelolosan air masuk melalui pori-pori papercrete terhadap sampel beton berumur 28 hari. Hasil pengujian diperoleh kedalaman penetrasi air terkecil pada benda uji KSP 111 sebesar 0,0278m, sedangkan kedalaman penetrasi air terbesar pada benda uji KSP 311 senilai $0,0427 \mathrm{~m}$. Hasil analisis koefisien permeabilitas paling kecil pada benda uji KSP 111 sebesar $2,13505 \times 10^{-7} \mathrm{~m} / \mathrm{dt}$ dan paling besar pada benda uji KSP 311 senilai 2,29956 $\times 10^{-6} \mathrm{~m} / \mathrm{dt}$. Papercrete menjadi salah satu alternatif material ramah lingkungan dipergunakan untuk keperluan non-struktural seperti partisi untuk dinding, pengganti bahan paving block, panel untuk dinding dan sumur resapan.
\end{abstract}

Kata Kunci: Papercrete, Nilai Penetrasi dan Permeabilitas, Variasi Campuran

\section{PENDAHULUAN}

Beton sebagai salah satu jenis bahan konstruksi bangunan sipil paling sering banyak dipergunakan oleh kalangan masyarat luas terutama masyarakat berprofesi menjadi kontraktor (pelaksana). Perkembangan ekonomi dunia yang semakin pesat pada masa sekarang ini akan membuat bangunan bermaterial beton tumbuh besar di banyak tempat sehingga mengakibatkan jumlah produksi beton juga akan mengalami peningkatan secara signifikan. Pembuatan beton sering disamakan dengan sesuatu hal yang hanya merusak lingkungan semata mulai dari proses menggali batu kapur sebagai perekatnya, pembakaran, hasil emisinya dan lain sebagainya. Oleh karena itu, maka segera mengembangkan suatu beton yang terbuat dari material ramah lingkungan sehingga nantinya tidak perlu lagi pembangunan tidak bisa terselesaikan dengan alasan demi menjaga keberlanjutan lingkungan (Hardjito, 2010).

Papercrete adalah suatu material bangunan baru yang terdiri dari pulped daur ulang serat kertas dengan semen portland atau tanah liat dan atau kotoran lainnya sebagai tambahan. Papercrete sendiri mempunyai tiga masalah utama yaitu jamur, penyusutan dan juga waktu pengeringan yang lebih lambat. Permasalahan mendasar mengenai jamur mungkin yang paling serius dan juga yang paling sulit untuk menghindarinya. Hal ini dikarenakan papercrete bertindak seperti spons, menyerap air dan juga wicking dengan baik di luar titik masuknya. Papercrete memiliki kecenderungan untuk bisa menyerap air, baik melalui kondensasi ataupun sebagai cairan sebagai tandatanda ada suatu kebocoran (Rama dan Sudhir, 2008).

Papercrete dapat dimasukkan ke dalam jenis beton ringan karena diperoleh dengan cara mencampurkan material bubur kertas yang memiliki berat relatif ringan bersama kapur putih, portland semen dan air. Material kertas sangat ramah lingkungan karena signifikan berasal dari full content daur ulang limbah kertas. Papercrete memiliki respons yang jauh lebih lembut dan lebih tinggi untuk keperluan fungsi redaman dan penyerapan energi. Bangunan (Bashar, 2009).

Kertas apabila dilihat material pembentuknya merupakan bagian dari rangkaian serat cellulose kayu (material yang berserat). Cellulose ini termasuk material terbanyak kedua setelah bahan batu yang ada di dunia ini. Cellulose (selulosa) merupakan bahan polimer alam yang memiliki gugusan rantai terhubung dengan molekul gula terbentuk dari molekul-molekul yang lebih kecil sehingga material menjadi pembentuk utama dinding kayu tanaman hijau yang juga menjadi bahan kain hingga diperoleh 
kertas. Gugusan rantai ini mengandung banyak hidrogen yang mengikat molekul $\mathrm{OH}$ dengan sifat ikatan yang kaku, mengkristal, stabil dan kuat sehingga hidrogen menjadikan dasar kekuatan beton kertas. Material beton kertas bisa ditambahkan bahan-bahan lain untuk memperkuat dan memperkaya variasinya seperti pelapisan bahan semen memperkuat jaringannya, sedangkan penggunaan bahan kaolinite akan membuat material lebih halus dan juga menimbulkan efek semi glossy. Material ini diuji dengan cara dipendam dalam tanah dan hasilnya menunjukkan bahwa material ini secara signifikan tahan terhadap bakteri dan tetap utuh (Pribadi, 2010).

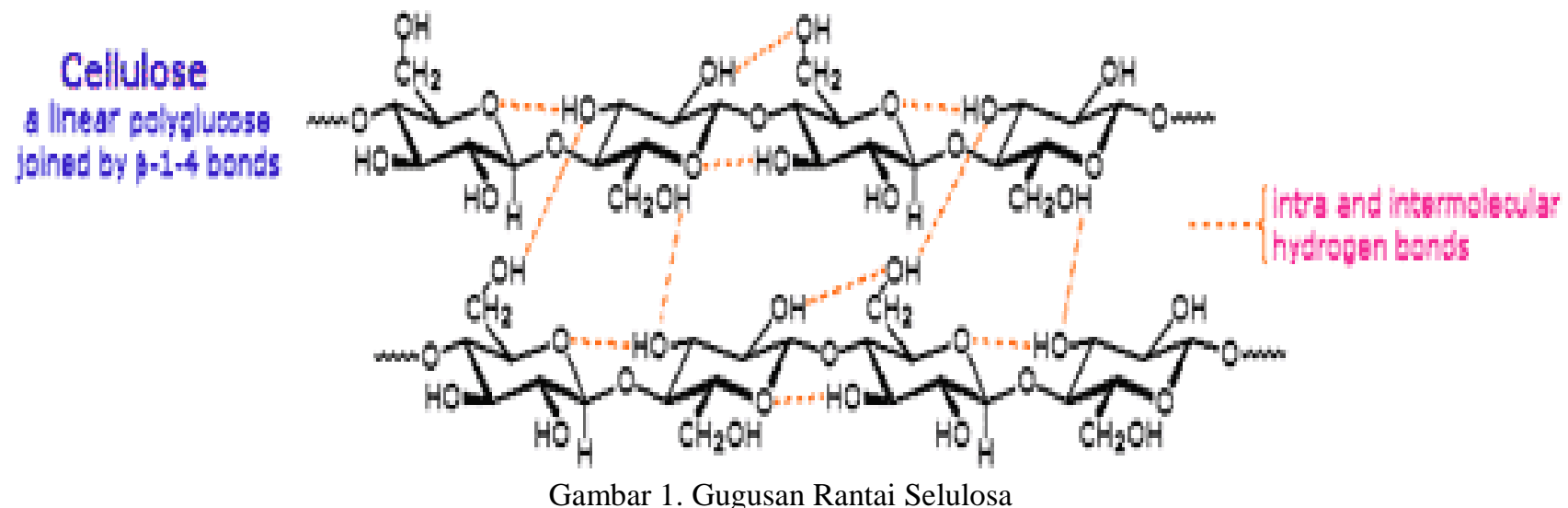

Sumber: Pribadi (2010)
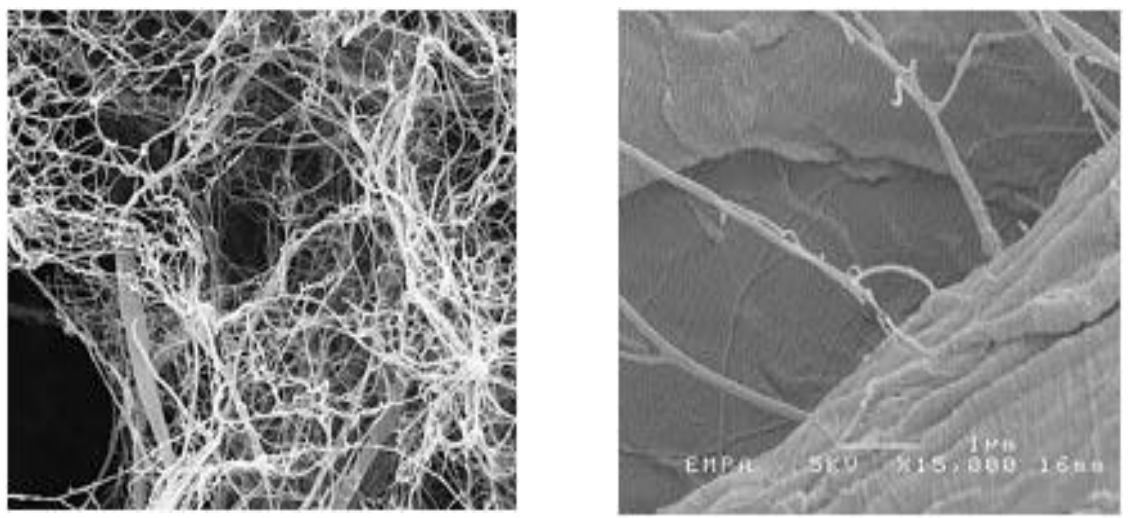

Gambar 2. Cellulose Fibers Melekat Kuat Dengan Ikatan Hidrogen Satu Sama Lainnya Sumber: Pribadi (2010)

Menurut Neville (2011) permeabilitas beton ialah kemudahan beton untuk dapat dialui air. Pasta semen yang sudah mengeras tersusun atas banyak partikel dihubungkan antar permukaan yang jumlahnya relatif lebih kecil dari total permukaan partikel yang ada. Air memiliki viskositas yang tinggi, akan tetapi dapat bergerak dan merupakan bagian dari aliran yang terjadi. Pengujian permeabilitas terdiri dari 2 macam jenis yaitu uji aliran (flow test) adalah pengujian yang bisa dilakukan untuk mengukur permeabilitas beton terhadap air apabila air dapat mengalir melalui sampel beton dan uji penetrasi (penetration test) ialah pengujian permeabilitas beton tidak ada air yang mengalir terhadap sampel. Hasil data pada pengujian permeabilitas digunakan untuk menentukan nilai koefisien permeabilitas yang mana menunjukkan suatu angka kecepatan rembesan fluida dalam suatu zat.

Masuknya air pada beton dapat terjadi pada bagian-bagian struktur bangunan yang berhubungan langsung dengan air seperti plat beton untuk atap, bak tampungan air, dinding basement dan lain sebagainya. Beton yang mudah jenuh oleh air (permeabilitas besar) akan mudah pula terkena serangan cuaca. Permeabilitas beton ini penting untuk konstruksi bangunan dan kekuatan serta lamanya beton dapat bertahan (keawetan beton). Nilai permeabilitas beton semakin kecil mengindikasikan air yang dapat masuk dalam konstruksi beton juga semakin sedikit sehingga beton akan lebih kuat, awet dan umur pemakaiannya juga semakin lama. Hal ini menunjukkan besarnya penetrasi dan permeabilitas sangat berpengaruh terhadap durabilitas struktur beton yang mengakibatkan beton yang kemasukan banyak sekali air akan mengalami penurunan kekuatan dan ketahanannya terhadap adanya pengaruh lingkungan sekitarnya (Widyawati, 2011).

\section{METODE PENELITIAN}

Pada penelitian ilmiah diperlukan langkahlangkah atau metode kerja yang runtut dan teratur mengenai suatu masalah, kasus, gejala, fenomena atau lainnya dengan jalan ilmiah agar mendapatkan sesuatu hasil ataupun jawaban yang sangat rasional, bisa diterima oleh khalayak umum dan dapat dipertanggungjawabkan akan kebenarannya.

Kajian ini menguraikan satu metode penelitian eksperimental yaitu metode yang bisa dilakukan dengan 
mengadakan suatu percobaan secara langsung untuk mendapatkan suatu data atau hasil yang menghubungkan antar variabel yang diselidiki. Pada penelitian eksperimen yang dilakukan di laboratorium dengan mengambil 2 jenis variabel yaitu variabel bebas berupa campuran adukan papercrete setiap variasi campuran dan variabel tak bebas berupa pengujian penetrasi dan permeabilitas beton.

Bahan yang dipergunakan dalam pembuatan bubur kertas pada campuran adukan papercrete adalah kertas koran bekas. Berdasarkan uji awal yang telah dilakukan sebelumnya, maka langkah-langkah pembuatan bubur kertas dapat dijabarkan sebagai berikut ini :

1. Kertas yang akan dicampur air dipotong menjadi bagian-bagian paling kecil untuk memudahkan dalam penyerapan air;

2. Potongan kertas dimasukkan kedalam ember berisi air dan dilakukan perendaman selama sekurang-kurangnya ialah 1 hari;

3. Kertas yang telah direndam kemudian diaduk dengan bor yang telah dipasangi dengan pengaduk adukan khusus;

4. Pengadukan dilakukan sampai diperoleh material bubur kertas yang sangat

halus.

Bubur kertas yang dirasakan sudah sangat halus kemudian dicampurkan dengan bahan portland cement (PC), pasir dan air sehingga terbentuklah suatu campuran adukan papercrete yang kompak dan kuat. Langkahlangkah pembuatan benda uji papercrete dapat diuraikan sebagai berikut ini :

1. Menyiapkan material dan peralatan yang akan digunakan untuk campuran adukan papercrete;

2. Menyiapkan suatu wadah atau tempat cetakannya papercrete;

3. Menimbang masing-masing bahan penyusun campuran adukan papercrete berdasarkan pada perhitungan mix design awal papercrete;

4. Membuat campuran adukan papercrete dengan cara manual, mengaduk material yang telah ditimbang memakai alat cangkul atau cetok semen;

5. Selanjutnya bisa dilakukan pengecoran dengan cara menuangkan adukan papercrete ke dalam cetakan dan memberi tanda untuk masing-masing sampel;

6. Kemudian dilakukan pemadatan, setelah cetakan beton terisi penuh maka permukaan diratakan dan dibiarkan selama kurang lebih 7x24 jam;

7. Membuka cetakan beton dan kemudian melakukan perawatan dengan mengangin-anginkan papercrete dalam suhu ruangan sampai batas waktu pengujian tiba selama kurang lebih 28 hari.

Benda uji berupa silinder beton yang terbuat dari campuran bubur kertas, portland cement (PC), pasir dan air yang dicetak ke dalam pipa PVC berdiameter 7,5 $\mathrm{cm}$ dengan tinggi $27,5 \mathrm{~cm}$ untuk pengujian permeabilitas pada papercrete. Penggunaan tambahan material bubur kertas pada campuran adukan papercrete dilakukan dengan cara variasi berat bubur kertas, portland cement, pasir dan air. Sampel benda uji berjumlah 9 buah dengan 3 buah benda uji tiap variasi campurannya untuk pengujian permeabilitas pada campuran adukan papercrete.

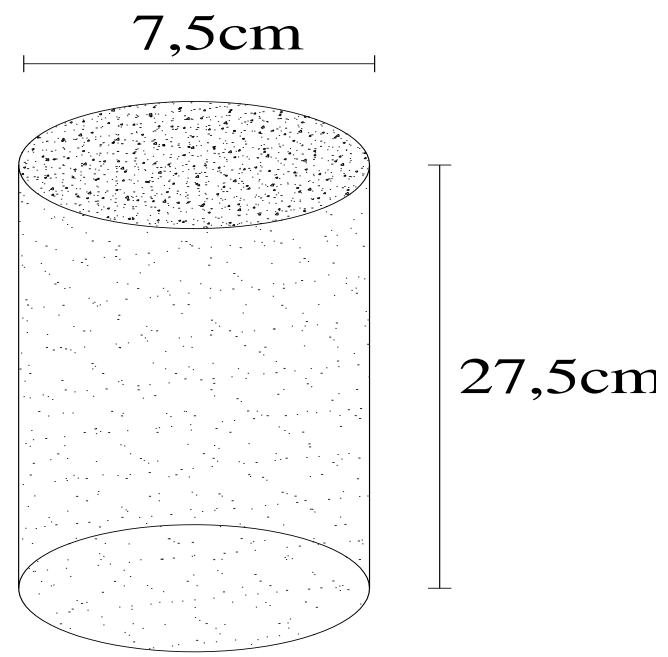

Gambar 3. Contoh Sampel Benda Uji Permeabilitas Sumber: Pribadi (2010)

Tabel 1. Sampel Benda Uji Permeabilitas Papercrete

\begin{tabular}{ccccc}
\hline No. & $\begin{array}{c}\text { Sampel } \\
\text { Benda } \\
\text { Uji }\end{array}$ & $\begin{array}{c}\text { Perbandingan } \\
\text { Campuran } \\
\text { K }: \text { S : P }\end{array}$ & Jumlah & $\begin{array}{c}\text { Umur } \\
\text { (Hari) }\end{array}$ \\
\cline { 1 - 4 } 1 & KSP 111 & $1: 1: 1$ & 3 & \multirow{2}{*}{28} \\
\cline { 1 - 4 } 2 & KSP 211 & $2: 1: 1$ & 3 & \\
\cline { 1 - 4 } 3 & KSP 311 & $3: 1: 1$ & 3 &
\end{tabular}

Sumber: Pribadi (2010)

Keterangan : KSP 211 : Campuran papercrete dengan perbandingan 2 Kertas : 1 Semen : 1 Pasir

Penelitian eksperimen ini telah dilakukan di Laboratorium Struktur dan Laboratorium Bahan Bangunan Jurusan Teknik Sipil Fakultas Teknik Universitas Sebelas Maret Surakarta berupa peralatan satu set alat uji permeabilitas beton yang terdiri dari :

1. Air compressors yang dipergunakan sebagai alat penghasil tekanan udara;

2. Tabung gas yang dilengkapi dengan pengukur tekanan berfungsi untuk pengumpul tekanan udara;

3. Selang tekanan untuk menyalurkan tekanan dari tabung ke benda uji;

4. Katup pengatur tekanan untuk mengatur keluar masuknya tekanan dan sebagai penghubung selang ke benda uji maupun tabung gas;

5. Selang transparan yang dipakai untuk mengukur penurunan aliran air;

6. Tiang penyangga untuk menggantungkan selang transparan agar dapat berdiri tegak.

Menurut Neville dan Brooks (2010) mekanisme suatu pengaliran pengujian permeabilitas beton dapat diukur dari sebuah percobaan sampel beton yang di-sealed air bertekanan pada sisi atasnya saja yang mencakup aspek banyaknya air yang mengalir lewat ketebalan beton pada satu waktu tertentu. Pengujian permeabilitas papercrete 
terhadap benda uji berbentuk silinder beton berdiameter $7,5 \mathrm{~cm}$ dengan tinggi $27,5 \mathrm{~cm}$ menggunakan mekanisme pengujian sebagai berikut ini :

1. Sampel beton yang berumur 28 hari dikeringkan memakai oven sampai diperoleh berat konstan;

2. Selang air bertekanan dipasang pada permukaan atas sampel dengan cara memberi lubang sebesar pipa selangnya. Pipa selang yang telah berisi air di-sealed di ikat $n$ klem pada atas permukaan beton;

3. Sampel beton yang telah terpasang dikenakan air bertekanan $1 \mathrm{~kg} / \mathrm{cm}^{2}$ selama 48 jam, dilanjutkan air bertekanan $3 \mathrm{~kg} / \mathrm{cm}^{2}$ selama 24 jam dan air dengan tekanan $7 \mathrm{~kg} / \mathrm{cm}^{2}$ selama 24 jam;

4. Selang air bertekanan dilepas, kemudian dipasang selang transparan berisi air yang diletakkan pada penyangga, diamkan selama kurang lebih 1 menit untuk mengetahui penurunan air yang terjadi dan tingginya air jatuh;

5. Selanjutnya sampel beton dibelah menggunakan Compressing Testing Machine (CTM) dan langsung diukur kedalaman penetrasi airnya beserta diameter sebaran airnya;

6. Koefisien permeabilitas dihitung dengan persamaan NISS (2001) berdasarkan pada hasil pengujian dan pengukuran di laboratorium meliputi nilai kedalaman penetrasi air dalam beton, diameter penampang pipa, diameter penampang sebaran sampel beton, waktu penurunan air sebesar 60 detik, tinggi air mula-mula dan tinggi air akhir sampel beton.
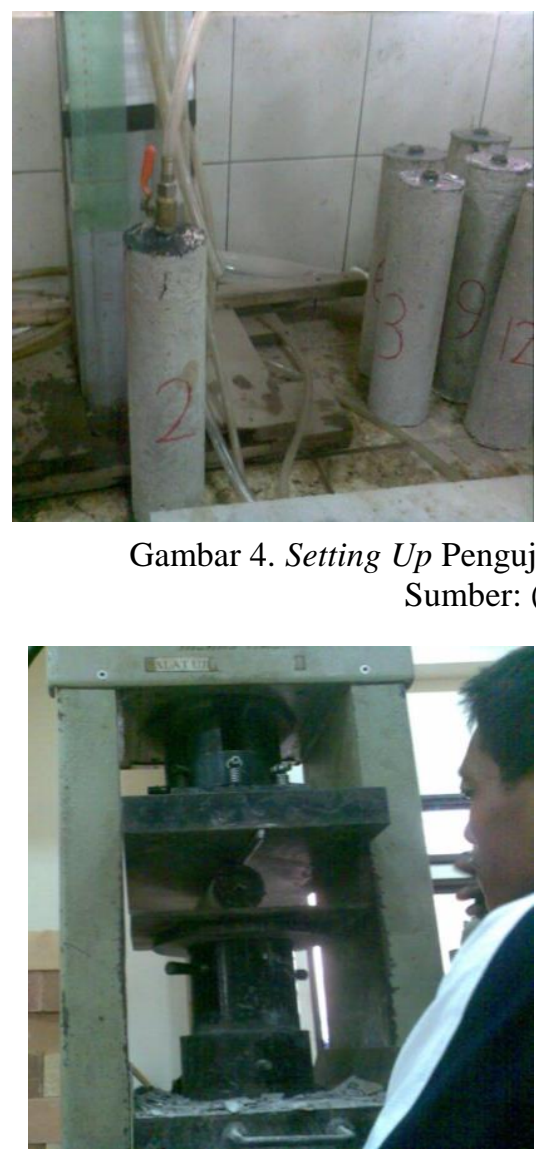

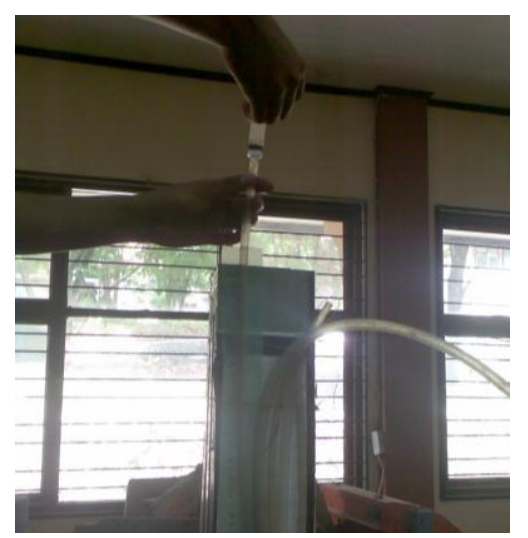

Gambar 4. Setting Up Pengujian Permeabilitas Pada Papercrete Sumber: (Pribadi, 2010)

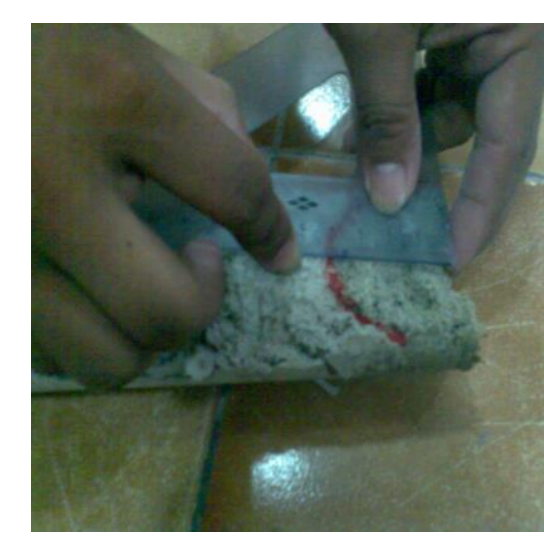

Gambar 5. Hasil Pengujian dan Pengukuran Penetrasi Pada Papercrete

Gambar 5. Hasil Pengujian dan Pengukuran Pent
Sumber: (Pribadi, 2010)

Besaran nilai koefisien permeabilitas dihitung dengan menggunakan persamaan NISS (2001) yang sudah dikombinasikan dan diintegrasikan sebagai berikut ini :

$$
\mathrm{k}=\left(\frac{A^{\prime} l}{A t}\right) \ln \left(\frac{h o}{h i}\right)
$$

Dimana k (1) adalah koefisien permeabilitas pada papercrete $(\mathrm{m} / \mathrm{dt})$, A' adalah luas penampang pipa $\left(\mathrm{m}^{2}\right), l$ adalah kedalaman penetrasi air $(\mathrm{m}), \mathrm{A}$ adalah luas penampang sebaran sampel beton $\left(\mathrm{m}^{2}\right), t$ adalah waktu penurunan air yang diperlukan (dt), ho adalah tinggi air mula-mula sampel beton $(\mathrm{m})$ dan hi adalah tinggi air akhir sampel beton $(\mathrm{m})$.

\section{HASIL PENELITIAN DAN PEMBAHASAN}

Pengujian penetrasi dan permeabilitas campuran adukan papercrete dilakukan terhadap sampel benda uji beton berdiameter 7,5 cm dengan tinggi $27,5 \mathrm{~cm}$ setelah umur beton mencapai 28 hari. Pengujian penetrasi dan permeabilitas bertujuan mengetahui besarnya kedalaman dan kelolosan air masuk ke dalam campuran adukan papercrete dengan cara memberi tekanan air pada benda uji sebesar $1 \mathrm{~kg} / \mathrm{cm}^{2}$ selama 48 jam, dilanjutkan dengan air bertekanan $3 \mathrm{~kg} / \mathrm{cm}^{2}$ selama 24 jam dan terakhir air bertekanan $7 \mathrm{~kg} / \mathrm{cm}^{2}$ selama 24 jam sesuai peraturan dan ketentuan yang berlaku. 
Hasil pengujian dan pengukuran kedalaman penetrasi air pada campuran adukan papercrete terhadap sampel benda uji beton sebanyak 9 buah dengan diameter $7,5 \mathrm{~cm}$ dan tinggi $27,5 \mathrm{~cm}$ setelah umur beton mencapai 28 hari dapat disajikan dalam bentuk tabel sebagai berikut ini.

Tabel 2. Hasil Pengujian Penetrasi Pada Papercrete

\begin{tabular}{|c|c|c|c|}
\hline No. & $\begin{array}{c}\text { Sampel } \\
\text { Benda Uji }\end{array}$ & $\begin{array}{l}\text { Kedalaman } \\
\text { Penetrasi Air } \\
\text { (m) }\end{array}$ & $\begin{array}{c}\text { Rata-Rata } \\
\text { Kedalaman } \\
\text { Penetrasi Air } \\
\text { (m) }\end{array}$ \\
\hline 1 & KSP $111 \underline{1}$ & 0,0275 & \multirow{3}{*}{0,0278} \\
\hline 2 & KSP $111 \underline{\mathbf{2}}$ & 0,0245 & \\
\hline 3 & KSP $111 \underline{\mathbf{3}}$ & 0,0315 & \\
\hline 4 & KSP $211 \underline{1}$ & 0,0336 & \multirow{3}{*}{0,0353} \\
\hline 5 & KSP $211 \underline{\mathbf{2}}$ & 0,0373 & \\
\hline 6 & KSP $211 \underline{\mathbf{3}}$ & 0,0350 & \\
\hline 7 & KSP $311 \underline{1}$ & 0,0418 & \multirow{3}{*}{0,0427} \\
\hline 8 & KSP $311 \underline{\mathbf{2}}$ & 0,0422 & \\
\hline 9 & KSP $311 \underline{\mathbf{3}}$ & 0,0440 & \\
\hline
\end{tabular}

Sumber: Pribadi (2010)

Contoh perhitungan rata-rata kedalaman penetrasi air untuk sampel benda uji KSP 111 dengan perbandingan campuran 1 kertas : 1 semen : 1 pasir adalah sebagai berikut :

Diketahui : $l_{1}=0,0275 \mathrm{~m} ; l_{2}=0,0245 \mathrm{~m} ; l_{3}=0,0315 \mathrm{~m}$

Nilai $l_{\text {rata-rata }}=\frac{l_{1}+l_{2}+l_{3}}{3}=\frac{0,0275+0,0245+0,0315}{3}$

Nilai Penetrasi $l_{\text {rata-rata }} \quad=0,0278 \mathrm{~m}$

Hasil analisis sampel benda uji KSP 111 dengan perbandingan campuran 1 kertas : 1 semen : 1 pasir memiliki nilai penetrasi terkecil, sedangkan sampel benda uji KSP 311 dengan perbandingan campuran 3 kertas : 1 semen : 1 pasir memiliki nilai penetrasi terbesar. Hal ini membuktikan penambahan prosentase material bubur kertas ke dalam campuran adukan papercrete menjadi faktor utama yang mempengaruhi menurunnya kualitas mutu papercrete dilihat dari parameter nilai penetrasinya.

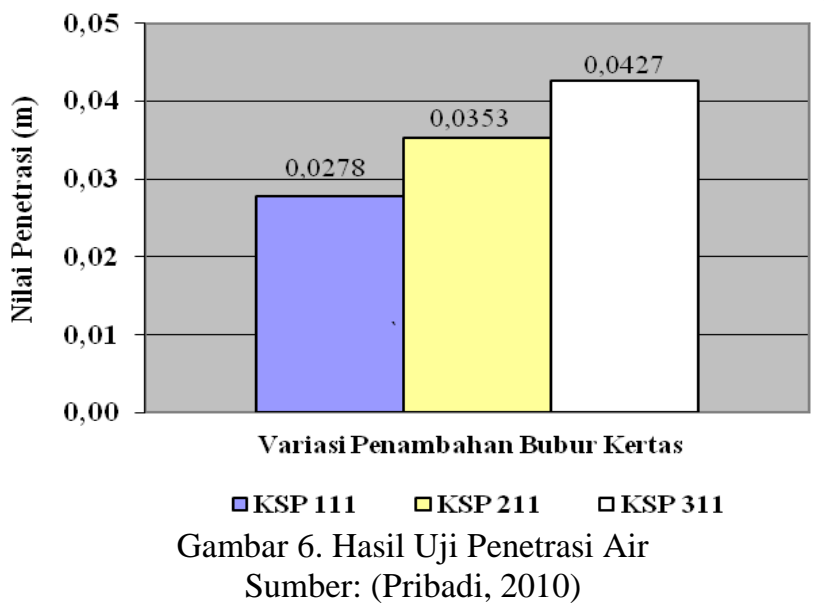

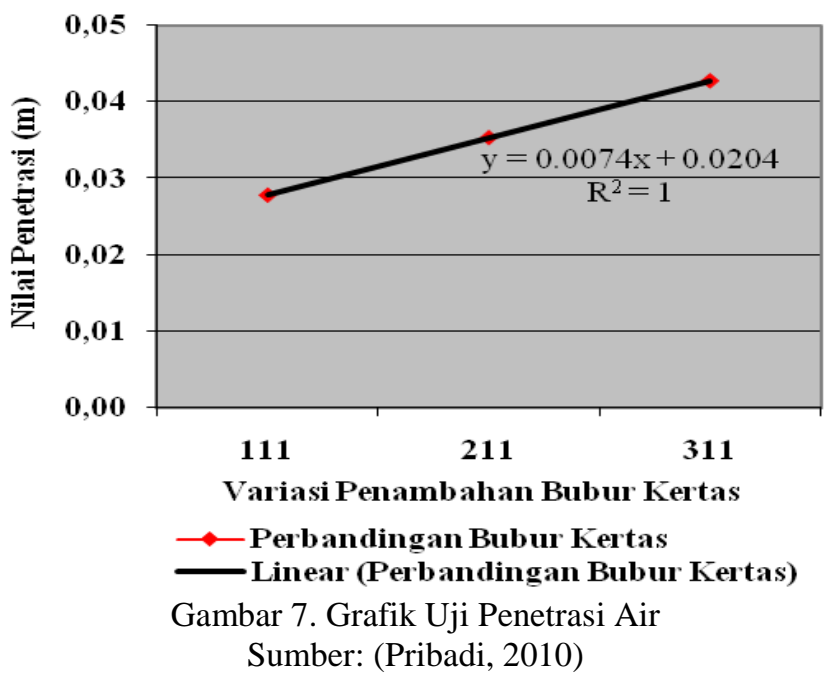

Dari grafik hubungan variasi penambahan bubur kertas dengan nilai penetrasi disimpulkan nilai kedalaman penetrasi akan semakin besar seiring adanya prosentase penambahan material bubur kertas pada campuran adukan papercrete. Material bubur kertas yang terbuat dari kertas koran kurang bisa menyatu sempurna secara homogen dengan pasta semen (campuran semen dan air) sehingga terbentuklah rongga-rongga udara yang mengakibatkan kepadatan beton semakin berkurang, beton bersifat porous dan permeabel serta kualitas mutu beton akan mengalami penurunan.

Contoh analisis nilai koefisien permeabilitas untuk sampel benda uji KSP 111 dengan perbandingan campuran 1 kertas : 1 semen : 1 pasir sebagai berikut ini :
Diketahui : Kedalaman penetrasi air $(l)=0,0275 \mathrm{~m}$
Diameter pipa (D') $\quad=0,007 \mathrm{~m}$
Diameter sampel beton $(\mathrm{d})=0,075 \mathrm{~m}$
Waktu penurunan air $(t) \quad=60$ detik
Tinggi air mula-mula (ho) $=0,70 \mathrm{~m}$
Tinggi air akhir (hi) $\quad=0,664 \mathrm{~m}$

Luas penampang pipa (A')

$$
\mathrm{A}^{\prime}=\frac{1}{4} \pi \mathrm{D}^{, 2}=\frac{1}{4} \times \pi \times 0,007^{2}=3,85 \times 10^{-5} \mathrm{~m}^{2}
$$

Luas penampang sebaran sampel beton (A)

$$
\text { A }=\frac{1}{4} \pi \mathrm{d}^{2}=\frac{1}{4} \times \pi \times 0,075^{2}=0,00442 \mathrm{~m}^{2}
$$

Nilai koefisien permeabilitas $(\mathrm{k})$ dapat dihitung dengan menggunakan persamaan NISS 2001 :

$$
\begin{aligned}
\mathrm{k} & =\left(\frac{A^{\prime} l}{A t}\right) \ln \left(\frac{h o}{h i}\right) \\
& =\left(\frac{3,85 \cdot 10^{-5} x 0,0275}{0,00442 \times 60}\right) \ln \left(\frac{0,70}{0,664}\right) \\
\mathrm{k} & =2,1379 \times 10^{-7} \mathrm{~m} / \mathrm{dt}
\end{aligned}
$$

Contoh perhitungan rata-rata nilai koefisien permeabilitas untuk sampel benda uji KSP 111 dengan perbandingan campuran 1 kertas : 1 semen : 1 pasir adalah sebagai berikut ini: 


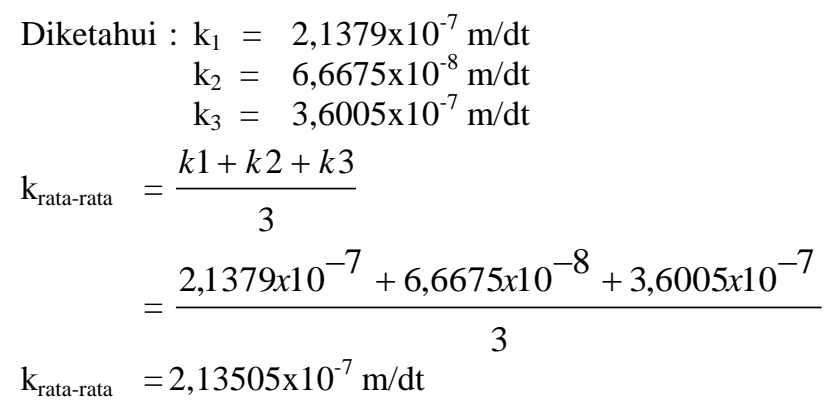

Hasil analisis sampel benda uji KSP 111 dengan perbandingan campuran 1 kertas : 1 semen : 1 pasir memiliki nilai koefisien permeabilitas terkecil, sedangkan sampel benda uji KSP 311 dengan perbandingan campuran 3 kertas : 1 semen : 1 pasir memiliki nilai koefisien permeabilitas terbesar. Hal ini menunjukkan penambahan prosentase material bubur kertas dalam campuran adukan papercrete menjadi salah indikator awal yang berpengaruh terhadap menurunnya kualitas mutu papercrete dilihat dari parameter nilai koefisien permeabilitasnya.

Tabel 3. Hasil Perhitungan Nilai Koefisien Permeabilitas Pada Papercrete

\begin{tabular}{|c|c|c|c|c|c|c|c|c|c|c|c|}
\hline No. & $\begin{array}{c}\text { Sampel } \\
\text { Benda Uji }\end{array}$ & $\begin{array}{c}l \\
(\mathrm{~m})\end{array}$ & $\begin{array}{l}\text { ho } \\
(\mathrm{m})\end{array}$ & $\begin{array}{l}\text { hi } \\
(\mathrm{m})\end{array}$ & $\begin{array}{c}\mathrm{t} \\
(\mathrm{dt})\end{array}$ & $\begin{array}{l}\mathrm{D}^{\prime} \\
(\mathrm{m})\end{array}$ & $\begin{array}{c}\mathrm{A}^{\prime} \\
\left(\mathrm{x} 10^{-6}\right) \\
\left(\mathrm{m}^{2}\right)\end{array}$ & $\begin{array}{c}\mathrm{d} \\
(\mathrm{m})\end{array}$ & $\begin{array}{c}\mathrm{A} \\
\left(\mathrm{m}^{2}\right)\end{array}$ & $\begin{array}{c}\mathrm{k} \\
\left(\mathrm{x} 10^{-6}\right) \\
(\mathrm{m} / \mathrm{dt})\end{array}$ & $\begin{array}{c}\text { Rata-Rata k } \\
\left(\mathrm{x} 10^{-6}\right) \\
(\mathrm{m} / \mathrm{dt})\end{array}$ \\
\hline 1 & KSP $111 \underline{1}$ & 0,0275 & 0,70 & 0,664 & 60 & 0,007 & 0,385 & 0,075 & 0,00442 & 0,21379 & \multirow{3}{*}{0,213505} \\
\hline 2 & KSP $111 \underline{\mathbf{2}}$ & 0,0245 & 0,70 & 0,687 & 60 & 0,007 & 0,385 & 0,075 & 0,00442 & 0,066675 & \\
\hline 3 & KSP $111 \underline{\mathbf{3}}$ & 0,0315 & 0,70 & 0,647 & 60 & 0,007 & 0,385 & 0,075 & 0,00442 & 0,36005 & \\
\hline 4 & KSP $211 \underline{1}$ & 0,0336 & 0,70 & 0,556 & 60 & 0,007 & 0,385 & 0,075 & 0,00442 & 1,1234 & \multirow{3}{*}{1,21904} \\
\hline 5 & KSP $211 \underline{\mathbf{2}}$ & 0,0373 & 0,70 & 0,518 & 60 & 0,007 & 0,385 & 0,075 & 0,00442 & 1,6305 & \\
\hline 6 & KSP $211 \underline{\mathbf{3}}$ & 0,0350 & 0,70 & 0,586 & 60 & 0,007 & 0,385 & 0,075 & 0,00442 & 0,90321 & \\
\hline 7 & KSP $311 \underline{1}$ & 0,0418 & 0,70 & 0,486 & 60 & 0,007 & 0,385 & 0,075 & 0,00442 & 2,2141 & \multirow{3}{*}{2,29956} \\
\hline 8 & KSP $311 \underline{\mathbf{2}}$ & 0,0422 & 0,70 & 0,458 & 60 & 0,007 & 0,385 & 0,075 & 0,00442 & 2,5989 & \\
\hline 9 & KSP $311 \underline{\mathbf{3}}$ & 0,0440 & 0,70 & 0,505 & 60 & 0,007 & 0,385 & 0,075 & 0,00442 & 2,0857 & \\
\hline
\end{tabular}

Sumber: Pribadi (2010)

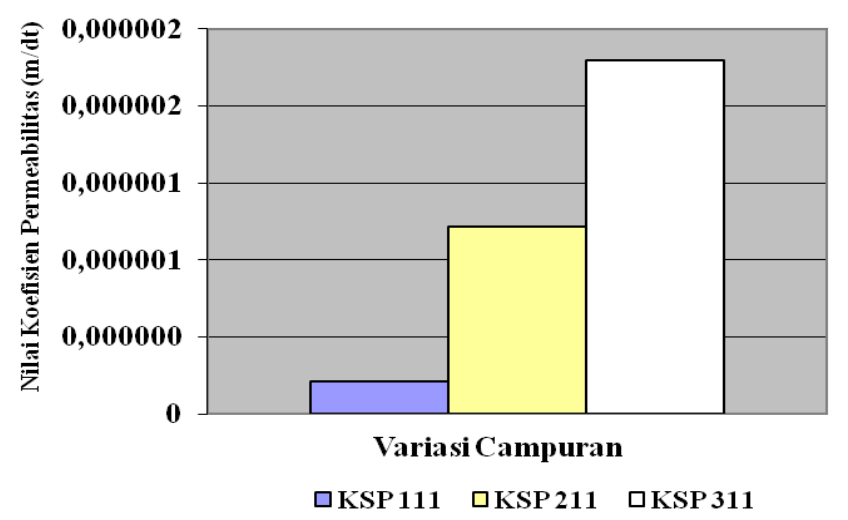

Gambar 8. Hasil Analisis Koefisien Permeabilitas Sumber: (Pribadi, 2010)

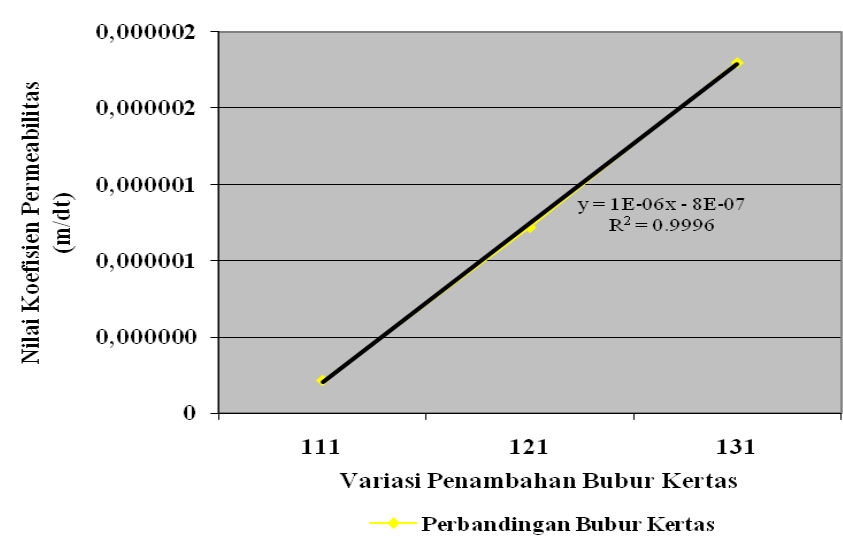

Gambar 9. Grafik Hasil Analisis Koefisien Permeabilitas Sumber: (Pribadi, 2010)
Pada campuran adukan papercrete prosentase penambahan bahan bubur kertas berjalan searah dengan nilai koefisien permeabilitasnya. Setiap adanya prosentase penambahan material bubur kertas ke dalam campuran adukan papercrete, maka akan diiringi oleh kenaikan nilai koefisien permeabilitasnya dan begitu juga sebaliknya. Kondisi ini mungkin disebabkan oleh air yang seharusnya digunakan untuk proses kimia hidrasi semen malah lebih cepat dan lebih banyak diserap oleh material bubur kertas sendiri sehingga proses hidrasi semen menjadi kurang sempurna yang mengakibatkan rongga-rongga permukaan beton semakin banyak terbentuk dan kepadatan beton menjadi semakin berkurang. Pada kondisi seperti ini beton lebih condong bersifat porous dan mudah dilalui oleh air (permeabel).

Sifat material kertas yang ada dalam campuran adukan papercrete hanya berfungsi sebagai bahan filler atau pengisi saja tanpa memberikan daya dukung yang baik terhadap sifat penetrasi dan permeabilitas beton pada campuran adukan papercrete. Selain itu juga, sifat bahan kertas yang sangat cepat dalam menyerap air dalam proses hidrasi semen menyebabkan papercrete memiliki nilai kekedapan yang sangat kecil pula, bersifat porous dan permeabel sehingga dapat disimpulkan bahwa bahan kertas kurang bagus digunakan sebagai bahan yang disyaratkan dalam pembuatan beton kedap air menurut peraturan dan ketentuan yang berlaku.

\section{KESIMPULAN}

Hasil pengujian dan perhitungan pada campuran adukan papercrete diperoleh benda uji KSP 111 memiliki 
nilai kedalaman penetrasi air dan koefisien permeabilitas paling kecil berturut-turut $0,0278 \mathrm{~m}$ dan $0,213505 \times 10^{-6}$ $\mathrm{m} / \mathrm{dt}$, sedangkan benda uji KSP 311 memiliki nilai kedalaman penetrasi air dan koefisien permeabilitas beton paling besar berturut-turut sebesar 0,0427 $\mathrm{m}$ dan 2,29956 $\mathrm{x}$ $10^{-6} \mathrm{~m} / \mathrm{dt}$. Penambahan prosentase material bubur kertas ke dalam campuran adukan papercrete akan meningkatkan nilai kedalaman penetrasi air dan koefisien permeabilitas. Kondisi ini mungkin disebabkan oleh air yang seharusnya digunakan untuk proses kimia hidrasi semen malah lebih banyak dan cepat diserap oleh material bubur kertas koran sehingga campuran adukan papercrete menjadi kurang bisa menyatu sempurna secara homogen dengan pasta semen (campuran semen dan air) dan mengakibatkan terbentuknya rongga-rongga udara yang semakin banyak.

Rongga-rongga udara yang banyak terbentuk pada papercrete dapat mengurangi kepadatan beton, beton lebih condong bersifat porous dan mudah dilalui oleh air (permeabel) serta kualitas mutu beton juga mengalami penurunan. Sifat material kertas yang ada dalam campuran adukan papercrete hanya berfungsi sebagai bahan filler atau pengisi saja tanpa memberikan daya dukung yang baik terhadap sifat penetrasi dan permeabilitas beton pada campuran adukan papercrete. Kondisi ini membuktikan bahwa material kertas kurang bagus digunakan sebagai bahan yang disyaratkan dalam pembuatan beton kedap air menurut peraturan dan ketentuan yang berlaku. Papercrete hanya dipergunakan untuk keperluan non-struktural seperti partisi untuk dinding, pengganti bahan paving block, panel untuk dinding dan juga sumur resapan yang terbuat dari material ringan dan ramah lingkungan.

\section{SARAN}

Dalam usaha menindaklanjuti penelitian ini ada kiranya perlu dilakukan beberapa koreksi agar penelitian selanjutnya dapat lebih baik dan tepat hasil. Adapun saran yang dapat diberikan untuk penelitian selanjutnya bisa dijelaskan sebagai berikut ini :

1. Perlu memastikan bahwa alat-alat yang akan digunakan dalam kondisi baik;

2. Perlu dilakukan pengujian untuk umur papercrete lebih dari 28 hari. Hal ini mengingat bahwa material kertas sangat cepat bereaksi dengan bahan-bahan penyusun beton pada umumnya;

3. Pada penelitian ini, pemberian tekanan sebesar 1 $\mathrm{kg} / \mathrm{cm}^{2}$ selama 48 jam, dilanjutkan air bertekanan 3 $\mathrm{kg} / \mathrm{cm}^{2}$ selama 24 jam dan terakhir air dengan tekanan $7 \mathrm{~kg} / \mathrm{cm}^{2}$ selama 24 jam tidak dapat stabil karena adanya penurunan akibat rembesan. Oleh karena itu, setiap kali terjadi penurunan air harus diikuti dengan kenaikan tekanan sesuai dengan ketentuan;

4. Perlu diadakan penelitian terhadap penambahan zat aditif (zat/bahan khusus lain) yang sesuai dengan sifat dan karakteristik papercrete yang dapat mengurangi penyerapan air oleh bahan kertas itu sendiri.

\section{DAFTAR PUSTAKA}

Bashar, M. S. (2009). "Papercrete As Infill Materials For Composite Wall System". Senior Lecturer, Civil Engineering Department, Universiti Tenaga Nasional, Selangor, Republik Nasional Malaysia. Tersedia di : http://www.eurojournals.com/ejsr.pdf.

Hardjito, D. (2010). "Pembangunan Berkelanjutan Material Beton Ramah Lingkungan dan Edukasi Mahasiswa." Seminar Nasional Lingkungan Hidup, Jurusan Teknik Sipil Universitas Kristen Petra, Surabaya.

Neville, A.M. (2011). Properties of Concrete. $5^{\text {th }}$ ed. London, Longman Group UK.

Neville, A.M, and Brooks, J. J. (2010). Concrete Technology. $2^{\text {nd }}$ ed. London, Longman Group UK.

Pribadi, Arqowi. (2010). "Tinjauan Absorpsi dan Permeabilitas Beton Kertas Pada Variasi Campuran." Tugas Akhir, Jurusan Teknik Sipil Fakultas Teknik, Universitas Sebelas Maret Surakarta, Surakarta.

Rama, J.S.K, and Sudhir, V.R. (2008). "Papercrete". VR Siddhartha Engineering College (Autonomous). Department Of Civil Engineering, Republik Nasional India. Tersedia di : ram.heaven@gmail.com dan lakshmiyouth.89@gmail.com.

Widyawati, R. (2011). "Serapan, Penetrasi dan Permeabilitas Beton Ringan." Seminar Nasional Sains dan Teknologi - IV, Program Studi Teknik Sipil, Jurusan Teknik Sipil Universitas Lampung, Bandar Lampung. 